\title{
Dissolved molybdenum asymptotes in sulfidic waters
}

\section{G.R. Helz*}

Abstract

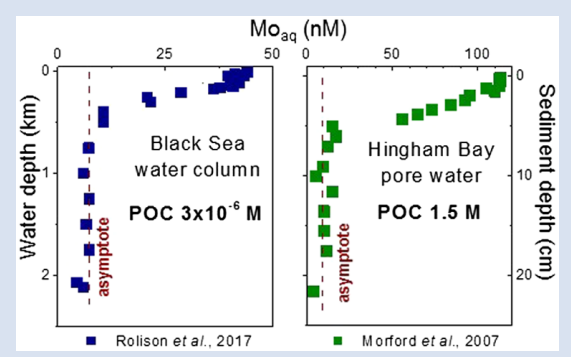

Molybdenum enrichment in organic-rich sediments is well known and is an accepted proxy for sulfidic conditions during sedimentation, but debate persists about how Mo enrichment arises. Organic scavenging and sulfide precipitation are the processes most often invoked. When dissolved $\mathrm{Mo}\left(\mathrm{Mo}_{\mathrm{aq}}\right)$ precipitates solely within sulfidic pore waters of sediments, contiguous particulate organic carbon concentrations (POC) are orders of magnitude higher than when it precipitates in euxinic water columns. Nevertheless, in both cases, $\mathrm{Mo}_{\mathrm{aq}}$ concentrations decline until reaching quite similar asymptotes centred around $7.8 \mathrm{nM}$. That $\mathrm{Mo}_{\mathrm{aq}}$ asymptotes are independent of organic carbon availability is inconsistent with organic scavenging as the dominant Mo fixing mechanism. In contrast, the $\mathrm{FeMoS}_{4}$ precipitation mechanism predicts both the existence of asymptotes and their POC independence. Because asymptotes block quantitative $\mathrm{Mo}_{\mathrm{aq}}$ precipitation, final $\delta^{98} \mathrm{Mo}$ values in euxinic marine sediments are apt to be offset from those in seawater, but the difference is small in modern environments because $\left(\mathrm{Mo}_{\mathrm{aq}}\right)_{\text {asymptote }}<<\left(\mathrm{Mo}_{\mathrm{aq}}\right)_{\text {seawater }}$. Asymptotes lie above the $\mathrm{Mo}_{\mathrm{aq}}$ concentration believed to limit $\mathrm{Mo}$ nitrogenase biosynthesis, suggesting that without substantial acidification, global euxinia cannot deplete $\mathrm{Mo}_{\mathrm{aq}}$ sufficiently to create marine nitrogen crises.

Received 16 December 2020 | Accepted 10 September 2021 | Published 15 October 2021

\section{Existence and Characteristics of Asymptotes}

In the oxic ocean, dissolved $\mathrm{Mo}\left(\mathrm{Mo}_{\mathrm{aq}}\right)$ is almost entirely $\mathrm{MoO}_{4}{ }^{2-}$. Particulate $\mathrm{Mo}\left(\mathrm{Mo}_{\mathrm{s}}\right)$ constitutes $<0.001 \%$ of $\Sigma \mathrm{Mo}$, except near terrigenous or hydrothermal particle sources (Ho et al., 2018). However, where $\mathrm{H}_{2} \mathrm{~S}$ or $\mathrm{HS}^{-}$replaces dissolved $\mathrm{O}_{2}, \mathrm{MoO}_{4}{ }^{2-}$ becomes thiolated, and $\mathrm{Mo}_{\mathrm{aq}}$ concentrations fall sharply toward asymptotes while $\mathrm{Mo}_{\mathrm{s}}$ in contiguous sediments rises. The resulting elevated $\mathrm{Mo}_{\mathrm{s}}$ is interpreted as signifying sulfide's presence during sedimentation.

A compilation in Table 1 shows that the span of $\mathrm{Mo}_{\mathrm{aq}}$ asymptote concentrations in diverse sulfidic environments is remarkably narrow. Entries in Table 1 meet the criteria that (a) a water column or pore water becomes sulfidic at depth, (b) $\mathrm{Mo}_{\mathrm{aq}}$ drops markedly (by $>50 \%$ ) below where sulfide first appears, and (c) $\mathrm{Mo}_{\mathrm{aq}}$ ultimately stabilises at asymptotes (designated $\left.\mathrm{Mo}_{\mathrm{aq}, \infty}\right)$ that are distinctly above analytical detection limits. The median asymptote value is $7.8 \mathrm{nM}$, and four fifths of the values fall in the range $2.5-13.3 \mathrm{nM}$. Asymptotes are prevalent in nature, but not universal; beneath some lakes and coastal embayments, pore water $\mathrm{Mo}_{\mathrm{aq}}$ concentrations fall to minima before rising at greater depths (see Morford et al., 2009; Dahl et al., 2010; Havig et al., 2015; Sulu-Gambari et al., 2017). The reason for this atypical pattern is unclear; infiltration of groundwater from surrounding uplands or very slow reductive dissolution of Mo-rich detrital phases sourced from nearby land may be contributing factors.

Of particular importance in Table 1 is the million-fold range of particulate organic carbon (POC) concentrations (expressed per unit volume of solution). For instance, during diagenesis, solutes in Hingham Bay's sulfidic pore waters are in diffusive contact with $\sim 1.5$ moles POC/L (calculated for sediments with $3.2 \%$ total organic carbon, porosity $=0.8$, and $2.5 \mathrm{~g} / \mathrm{cm}^{3}$ dry density; see Note II in the Supplementary Information). In contrast, measured POC concentrations in the Black Sea's sulfidic

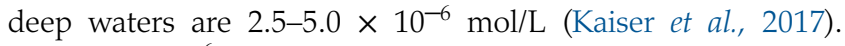
Despite the $10^{6}$ difference, similar $\mathrm{Mo}_{\mathrm{aq}, \infty}$ asymptotes occur in both places. It could be argued that a mismatch in renewal rates of water and organic particles in the Black Sea makes this apparent POC disparity misleading. Below $1 \mathrm{~km}$ depth, the Black Sea's water is renewed every $\sim 10^{3}$ yr whereas its POC is renewed every $\sim 10^{1}$ yr (estimated from the POC accumulation rate in underlying sediments; Arthur et al., 1994). Thus, deep water is cumulatively exposed to $10^{2}$ times more POC than is present instantaneously. On this basis, the Black Sea's POC concentration is only $10^{4}$, rather than $10^{6}$, times smaller than Hingham Bay's, but the disparity is still huge.

Asymptotes are likewise insensitive to final $S^{-I I}$ concentrations (Table 1). For example, the maximum $\mathrm{S}^{-\mathrm{II}}$ concentration in the Black Sea is $0.4 \mathrm{mM}$ and that in Kyllaren Fjord is $5.0 \mathrm{mM}$, but both reach similar $\mathrm{Mo}_{\mathrm{aq}, \infty}$ asymptotes. The extreme $\mathrm{Mo}_{\mathrm{aq}, \infty}$ asymptotes in Table 1 (i.e. Walker Lake, $130 \mathrm{nM}$, and York River, $1.1 \mathrm{nM}$ ) mirror $\mathrm{pH}$ extremes, hinting that $\mathrm{pH}$ explains some of the asymptote variation, though the data are insufficient to establish this for certain. Any explanation for $\mathrm{Mo}_{\mathrm{aq}}$ removal from sulfidic natural waters must account for why asymptotes are insensitive to $\Sigma \mathrm{S}^{-\mathrm{II}}\left(=\mathrm{H}_{2} \mathrm{~S}_{\mathrm{aq}}+\mathrm{HS}^{-}\right)$and $\mathrm{POC}$, but possibly sensitive to $\mathrm{pH}$. 
Table 1 Limits to the degree of dissolved Mo removal from sulfidic environments (Mo aq, $0=$ dissolved Mo at onset of sulfidic conditions; $\mathrm{Mo}_{\mathrm{aq}, \infty}=$ dissolved Mo at asymptote; $\mathrm{S}^{-11}$ is total dissolved sulfide range over depths where $\mathrm{Mo}_{\mathrm{aq}, \infty} \approx$ constant). For sources of data, see Note I in the Supplementary Information.

\begin{tabular}{|c|c|c|c|c|c|c|}
\hline Removal within: & $\mathrm{pH}$ & $\begin{array}{l}\mathrm{S}^{-\mathrm{II}} \\
(\mathrm{mM})\end{array}$ & $\begin{array}{l}\text { Particulate } \\
\text { POC* }(\mathrm{mM})\end{array}$ & $\begin{array}{l}\mathrm{Mo}_{\mathrm{aq}, 0}, \\
(\mathrm{nM})\end{array}$ & $\begin{array}{c}\mathrm{Mo}_{\mathrm{aq}, \infty} \\
(\mathrm{nM})\end{array}$ & $\begin{array}{c}\mathrm{Mo}_{\mathrm{aq}, \infty} / \mathrm{Mo}_{\mathrm{aq}, 0} \\
(\%)\end{array}$ \\
\hline \multicolumn{7}{|l|}{ Euxinic marine water columns } \\
\hline Black Sea (1991) & & $0.30-0.41$ & 0.0025 & 36 & 2.6 & 7 \\
\hline Black Sea (2011) & 7.6 & $0.30-0.37$ & & 37 & 7.8 & 21 \\
\hline Black Sea (2017 & & $0.35-0.42$ & $0.0025-0.005$ & 41 & 5.9 & 14 \\
\hline Black Sea (2019) & 7.34 & $0.31-0.36$ & & 36 & 6.9 & 19 \\
\hline Framvaren Fjord & 7.1 & $0.30-7.20$ & $0.0027 \pm 0.0006$ & 50 & 17.2 & 34 \\
\hline Kyllaren Fjord & & $4.23-5.02$ & $0.003-0.008$ & 71 & 7.5 & 11 \\
\hline Rogoznica Lake (Sept.) & 7.2 & $0.42-2.34$ & $0.24 \pm 0.10$ & 97 & 4.5 & 5 \\
\hline \multicolumn{7}{|l|}{ Sulfidic pore waters } \\
\hline Chesapeake Bay & 7.2 & 1.15 & & 55 & 7.8 & 14 \\
\hline Guaymas Basin (MUC9, >25 cm) & & $0.12-0.43$ & $1580 \pm 68$ & 130 & 12.3 & 9 \\
\hline Hingham Bay (Oct. 2001, >7 cm) & & $0.49-1.01$ & $1530 \pm 79$ & 112 & 9.3 & 8 \\
\hline Landsort Deep (LD 1) & & $1.73-2.09$ & $2200 \pm 900$ & 26 & 2.1 & 8 \\
\hline Long Island Sound (FOAM, $>20 \mathrm{~cm}$ ) & & $2.5-3.3$ & $680 \pm 120$ & 115 & 13.3 & 12 \\
\hline Storfjärden (Stn 3) & & $0.005-0.45$ & $2100 \pm 300$ & 30 & 8. & 27 \\
\hline Terrebonne Bay (9A) & 7.0 & $0.09-1.61$ & & 33 & 7.3 & 22 \\
\hline Walker Lake (WL-2) & 8.4 & $5.4-6.2$ & $620-1100$ & 5700 & 134. & 2 \\
\hline York River groundwater & 6.9 & $0.91-1.60$ & & 73 & 1.1 & 2 \\
\hline \multicolumn{7}{|l|}{ Euxinic lake water columns } \\
\hline Fayetteville Green Lake & 6.9 & $0.44-1.86$ & 0.066 & 121 & 13.2 & 11 \\
\hline Lago Cadagno (Aug 2007) & 7.1 & 0.10 & 0.0068 & 14 & 2.5 & 18 \\
\hline Lake Fryxell & 7.5 & $0.30-1.20$ & $0.062 \pm 0.023$ & 26 & 3.5 & 13 \\
\hline Mahoney Lake & 7.4 & 35.0 & & 230 & 12. & 5 \\
\hline Median & & & & & 7.8 & 12 \\
\hline
\end{tabular}

*Particulate POC concentrations are expressed per litre of solution. Where more than three POC measurements are available, mean \pm standard deviation is reported; otherwise, the range is given.

\section{Organic Scavenging}

The principal argument for organic scavenging rests on correlations commonly, but not universally, observed between $\mathrm{Mo}_{\mathrm{s}}$ and organic matter in sedimentary rocks. As reviewed by Helz and Vorlicek (2019), no satisfactory molecular mechanism to explain $\mathrm{Mo}_{\mathrm{aq}}$ scavenging by organic matter under natural conditions has yet been found, and evidence is also lacking for significant biological scavenging. If organic scavenging exists, it is likely to be an abiotic process that can be described by a Langmuir isotherm as:

$$
\frac{\mathrm{Mo}_{\mathrm{s}}}{x_{\mathrm{s}} \mathrm{POC}}=\left[\frac{K_{n}^{\prime} x_{n}}{1+K_{n}^{\prime} x_{n} \mathrm{Mo}_{\mathrm{aq}}}\right] \mathrm{Mo}_{\mathrm{aq}}
$$

where $\mathrm{Mo}_{\mathrm{s}}$ is non-lithogenic Mo adsorbed onto particulate organic carbon $\left(\mathrm{mol} \mathrm{Mo}_{\mathrm{s}} / \mathrm{L}\right), x_{\mathrm{s}}$ the mole fraction of a specific binding site ( $\mathrm{mol} \mathrm{sites} / \mathrm{mol} \mathrm{C}$ ), POC the particulate organic carbon concentration $(\mathrm{mol} / \mathrm{L}), K_{n}{ }^{\prime}$ the conditional binding constant $(\mathrm{L} / \mathrm{mol})$ for the $n^{\text {th }} \mathrm{MoO}_{4-n} \mathrm{~S}_{n}{ }^{2-}$ ion, and $x_{n}$ the mole fraction of the $n^{\text {th }}$ $\mathrm{MoO}_{4-n} \mathrm{~S}_{n}{ }^{2-}$ ion in $\mathrm{Mo}_{\text {aq }}$ (see Fig. 1).

For simplicity, Equation 1 assumes only one adsorbing $\mathrm{MoO}_{4-n} \mathrm{~S}_{n}{ }^{2-}$ species and only one binding site. Multiple species or sites could be included by adding more terms. At the $\mathrm{pH}$ and $\mathrm{Mo}_{\mathrm{aq}}$ concentrations of most sulfidic natural waters, the second term in the denominator is negligible, making isotherms linear. In the linear case, Equation 1 is tantamount to the empirical
$\mathrm{Mo}_{\mathrm{s}} / \mathrm{POC}$ vs. $\mathrm{Mo}_{\mathrm{aq}}$ relationship found for euxinic basin sediments by Algeo and Lyons (2006; see their Fig. 8a).

What does the linear form imply about aqueous asymptotes? Mass balance requires that:

$$
\mathrm{Mo}_{\mathrm{aq}}=\mathrm{Mo}_{\mathrm{aq}, 0}-\mathrm{Mo}_{\mathrm{s}}=\mathrm{Mo}_{\mathrm{aq}, 0}-x_{\mathrm{s}} \mathrm{POC}\left[K_{n}^{\prime} x_{n}\right] \mathrm{Mo}_{\mathrm{aq}}
$$

where $\mathrm{Mo}_{\mathrm{aq}, 0}$ is the initial total dissolved $\mathrm{Mo}$ and $\mathrm{Mo}_{\mathrm{aq}}$ is the same during adsorption progress. Rearranging:

$$
\frac{\mathrm{Mo}_{\mathrm{aq}}}{\mathrm{Mo}_{\mathrm{aq}, 0}}=\frac{1}{1+x_{\mathrm{s}} \mathrm{POC}\left[K_{n}^{\prime} x_{n}\right]}
$$

In diverse euxinic basins and sulfidic pore waters, asymptotes fix the ratio on the left hand side of this equation at a median value of $12 \%$ (seventh column, Table 1). This requires that in nature the denominator's second term has a restricted range centred near 8 . Given the $10^{6}$ range of its POC factor, this requirement cannot possibly be met. Additionally, at any specific site, the ratio on the left is roughly constant through the asymptote zone, requiring that the second term in the denominator is also constant. However, $\mathrm{H}_{2} \mathrm{~S}_{\mathrm{aq}}$ varies through asymptote zones (third column, Table 1 ), and $x_{n}$ values strongly vary with $\mathrm{H}_{2} \mathrm{~S}_{\mathrm{aq}}$ (Fig. 1). Only at high $\mathrm{H}_{2} \mathrm{~S}_{\mathrm{aq}}$ concentrations, where $x_{4}$ becomes sulfide independent, can Equation 3 describe constant asymptotes at a constant POC concentration. (In this case, $x_{4}$ replaces $x_{n}$ in Equation 3, implying that $\mathrm{MoS}_{4}{ }^{2-}$ is the only adsorbed 


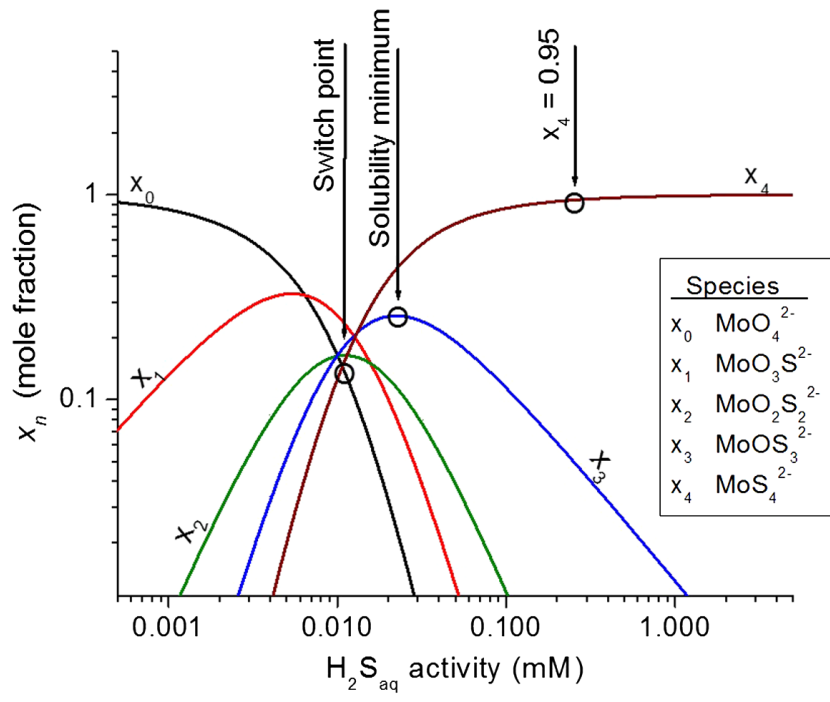

Figure 1 Mole fractions of aqueous $\mathrm{MoO}_{4-n} \mathrm{~S}_{n}{ }^{2-}$ species versus the activity of $\mathrm{H}_{2} \mathrm{~S}_{\mathrm{aq}}$, which is the non-ionised fraction of total dissolved sulfide. Circles mark three special points: where $\mathrm{MoO}_{4}{ }^{2-}=$ $\mathrm{MoS}_{4}{ }^{2-}$ (switch point); where $x_{3}$ reaches its maximum (corresponding to the solubility minimum); and where $x_{4} \geq 0.95$, signifying effective completion of $\mathrm{Mo}_{\mathrm{aq}}$ thiolation.

species.) However, $\mathrm{H}_{2} \mathrm{~S}_{\mathrm{aq}}$ concentrations high enough for $x_{4}$ to approach constancy exceed the concentrations at which $\mathrm{Mo}_{\mathrm{aq}}$ asymptotes commence in nature. For example, the $\mathrm{Mo}_{\mathrm{aq}}$ asymptote in the Black Sea commences at $\mathrm{H}_{2} \mathrm{~S}_{\mathrm{aq}} \approx 50 \mu \mathrm{M}$ (where $\Sigma \mathrm{S}^{-\mathrm{II}} \approx 300 \mu \mathrm{M}$ ), whereas Figure 1 shows that $\mathrm{H}_{2} \mathrm{~S}_{\mathrm{aq}}$ must be much higher, near $200 \mu \mathrm{M}$, for $x_{4}$ to come within $5 \%$ of its ultimate limiting value. Equation 3, which describes organic scavenging, therefore cannot explain $\mathrm{Mo}_{\mathrm{aq}}$ asymptotes.

\section{FeMoS $_{4}$ Precipitation}

Earlier workers rejected the possibility of Mo precipitation by sulfide. Emerson and Huested (1991) pointed out that, unlike sulfide-precipitated metals, $\mathrm{Mo}_{\mathrm{aq}}$ fails to decline continuously with increasing $\Sigma \mathrm{S}^{-\mathrm{II}}$. In agreement, Algeo and Lyons (2006) noted that Cariaco Basin sediments accumulate higher $\mathrm{Mo}_{\mathrm{s}}$ concentrations than Black Sea sediments, even though Cariaco waters contain less sulfide.

Nevertheless, Vorlicek et al. (2018) found a colloidal precipitate, $\mathrm{FeMoS}_{4}$, with a solubility that could explain $\mathrm{Mo}_{\mathrm{aq}}$ asymptotes in the Black Sea. At equilibrium with this precipitate (see derivation in Note III, Supplementary Information):

$$
\mathrm{Mo}_{\mathrm{aq}}=\frac{10^{-19.83} 10^{2 \mathrm{pH}}}{Q_{\mathrm{FeS}}\left(\gamma_{\mathrm{MoS}_{4}}\right)}\left(x_{3}\right)^{-1}
$$

where $\gamma_{\mathrm{MoS}_{4}}$ is the activity coefficient of $\mathrm{MoS}_{4}{ }^{2-}$ and $Q_{\mathrm{FeS}}=$ $\left\{\mathrm{Fe}^{2+}\right\}\left\{\mathrm{H}_{2} \mathrm{~S}_{\mathrm{aq}}\right\} /\left\{\mathrm{H}^{+}\right\}^{2}$. Except for the $x_{3}$ term, the factors on the righthand side of Equation 4 display limited variability in asymptote zones. $Q_{\mathrm{FeS}}$ values are usually constrained by saturation with iron monosulfide phases and $\mathrm{pH}$ is constrained mainly by strong $\Sigma \mathrm{CO}_{2} / \Sigma$ ALK buffering. On the other hand, $x_{3}$ varies considerably, passing through a maximum with increasing $\mathrm{H}_{2} \mathrm{~S}_{\text {aq }}$ activity (Fig. 1). In Table 2, values of $\mathrm{H}_{2} \mathrm{~S}_{\mathrm{aq}}$ at $x_{3}$ maxima have been estimated over a moderate temperature range by the isocoulombic extrapolation method (Gu et al., 1994). Equation 4 requires that at $x_{3}$ maxima, $\mathrm{Mo}_{\mathrm{aq}}$ solubility reaches minima; this is illustrated by dashed curves in Figure 2. However, aging transforms $\mathrm{FeMo}^{\mathrm{VI}} \mathrm{S}_{4}$ to an inert $\mathrm{Mo}^{\mathrm{IV}}$ phase, preventing Mo
Table 2 Concentrations of $\mathrm{H}_{2} \mathrm{~S}_{\mathrm{aq}}(\mu \mathrm{M})$ at selected temperatures and degrees of $\mathrm{MoO}_{4}{ }^{2-}$ thiolation (ionic strength $=0$ ).

\begin{tabular}{|c|c|c|c|}
\hline $\begin{array}{c}\text { Temperature } \\
\left({ }^{\circ} \mathrm{C}\right)\end{array}$ & $\begin{array}{c}\text { Switch point } \\
\left(\mathrm{MoO}_{4}{ }^{2-}=\right. \\
\left.\mathrm{MoS}_{4}{ }^{2-}\right)\end{array}$ & $\begin{array}{c}\text { Solubility } \\
\text { minimum } \\
\left(\mathrm{MoOS}_{3}{ }^{2-}\right. \\
\text { peak })\end{array}$ & $\begin{array}{c}x_{4}=0.95 \\
\text { (thiolation } \approx \\
\text { complete) }\end{array}$ \\
\hline 5 & 5 & 9 & 120 \\
25 & 11 & 21 & 260 \\
45 & 22 & 42 & 530 \\
\hline
\end{tabular}

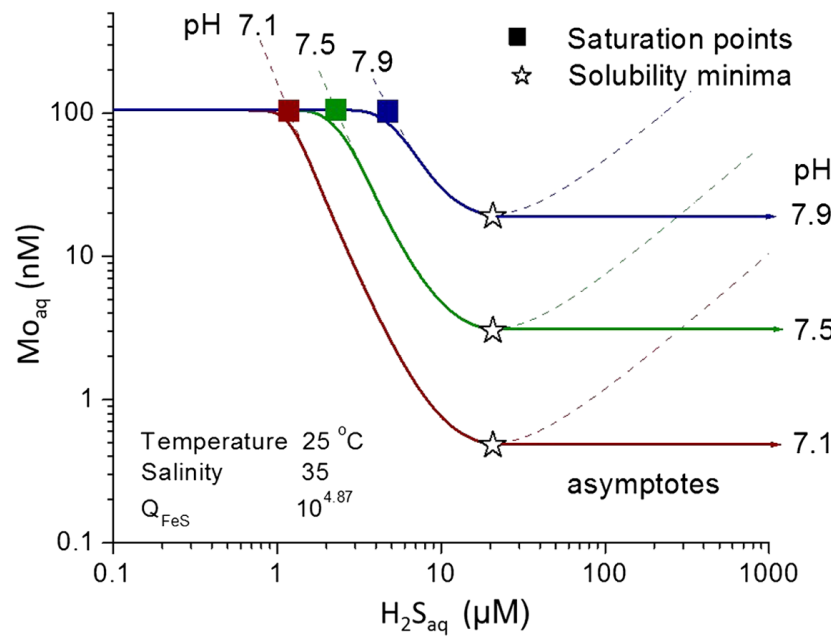

Figure 2 Effect of rising $\mathrm{H}_{2} \mathrm{~S}_{\mathrm{aq}}$ on $\mathrm{FeMoS}_{4}$ solubility (dashed curves) in seawater (initial $\mathrm{Mo}_{\mathrm{aq}}=105 \mathrm{nM}$ ) assuming saturation with $\mathrm{FeS}_{\text {nano, }}$ a material more soluble and reactive than mackinawite (Wolthers et al., 2005; Matamoros-Veloza et al., 2018). At $\mathrm{FeMoS}_{4}$ saturation points (squares), the solubility drops below ambient $\mathrm{Mo}_{\mathrm{aq}, 0}$ and precipitation begins. Eventually, solubility minima (stars) are reached. Actual $\mathrm{Mo}_{\mathrm{aq}}$ follows the heavy curves because an irreversible redox transformation blocks redissolution of precipitated Mo. Based on Equation 2 in Helz and Vorlicek (2019).

redissolution when the solubility curves turn upward beyond the minima. As a result, the $\mathrm{FeMoS}_{4}$ precipitation mechanism predicts that $\mathrm{Mo}_{\mathrm{aq}}$ becomes fixed at asymptotes that are unresponsive to further $\mathrm{H}_{2} \mathrm{~S}_{\mathrm{aq}}$ increases. The asymptotes are also independent of $\mathrm{POC}$, despite the $10^{6}$ range in nature, because organic matter has no role in the precipitation and aging reactions, except as fuel for biological sulfate reduction (Helz and Vorlicek, 2019). Thus $\mathrm{FeMoS}_{4}$ precipitation meets the requirements listed above for a mechanism that can explain asymptotes.

\section{Implications}

Several implications of interest in the palaeoproxy field arise from this result.

Asymptotes block quantitative removal of $\mathrm{Mo}_{\mathrm{aq}}$ from sulfidic waters, leaving dissolved residuals that ultimately escape the sulfidic environment. In the median case in Table 1 , the residual $\left(\mathrm{Mo}_{\mathrm{aq}, \infty} / \mathrm{Mo}_{\mathrm{aq}, 0}\right)$ is only $12 \%$ but can be much higher. This finding undermines the common assumption that marine euxinic basins preserve the $\delta^{98} \mathrm{Mo}$ signatures of global seawater because of quantitative precipitation. Residuals will be greatest in waters of lower salinity, where $\mathrm{Mo}_{\mathrm{aq}, 0}$ will be lower, and in 
waters of higher $\mathrm{pH}$, where $\mathrm{Mo}_{\mathrm{aq}, \infty}$ will be higher. Both situations generate higher $\mathrm{Mo}_{\mathrm{aq}, \infty} / \mathrm{Mo}_{\mathrm{aq}, 0}$ ratios at asymptotes, permitting larger fractions of incoming $\mathrm{Mo}_{\mathrm{aq}}$ to escape deposition.

The idea that $\mathrm{Mo}_{\mathrm{s}} / \mathrm{POC}$ ratios in sedimentary rocks can be used to estimate $\mathrm{Mo}_{\mathrm{aq}}$ in ancient basins (Algeo and Lyons, 2006, and others) relies on the relationship in Equation 1, which is premised on the dominance of POC scavenging. Without scavenging, such $\mathrm{Mo}_{\mathrm{aq}}$ estimates are ungrounded.

Table 1 shows that $\mathrm{Mo}_{\mathrm{aq}}$ asymptotes in the $\mathrm{pH}$ range of modern environments all exceed $1 \mathrm{nM}$, the level thought to curb nitrogen fixation by Mo-nitrogenase (Glass et al., 2010). Therefore, past global euxinia would not have shut down Mo-nitrogenase activity, creating marine nitrogen crises, unless accompanied by substantial acidification, which lowers $\mathrm{Mo}_{\mathrm{aq}, \infty}$ (Fig. 2).

Can $\mathrm{FeMoS}_{4}$ precipitation explain why the Black Sea produces lower sedimentary $\mathrm{Mo}_{\mathrm{s}}$ despite higher bottom water $\mathrm{H}_{2} \mathrm{~S}_{\mathrm{aq}}$ concentrations compared to the Cariaco Basin? Consistent with the organic scavenging mechanism (Eq. 1), Algeo and Lyons (2006) regarded bottom water $\mathrm{Mo}_{\mathrm{aq}}$ concentration, which is lower in the Black Sea, as the controlling variable. The Black Sea's lower bottom water $\mathrm{Mo}_{\mathrm{aq}}$ concentration, and consequent lower sediment $\mathrm{Mo}_{\mathrm{s}}$ concentration, were attributed to a $\mathrm{Mo}_{\mathrm{aq}}$ supply restriction at the narrow Bosporus. This explanation is probably incorrect. The Bosporus distributes 4-5 times more $\mathrm{Mo}_{\mathrm{aq}}$ into the Black Sea than its sediments accumulate (Piper and Calvert, 2009), and the excess returns through the Bosporus. On the other hand, the Bosporus restricts the Black Sea's river water throughput. Copious river inflow lowers surface salinity and intensifies density stratification, thus inhibiting introduction of oxidants into deep waters. Consequently, $\Sigma \mathrm{S}^{-\mathrm{II}}$ accumulates sufficiently for the FeMoS 4 saturation point to ascend into the water column, causing $\mathrm{Mo}_{\mathrm{aq}}$ drawdown there. Cariaco's better ventilation, attested by its shorter water residence time, suppresses $\Sigma S^{-I I}$ despite opposition from a greater POC rain rate. This confines Cariaco's saturation point to pore waters. Calculations based on $\Sigma \mathrm{S}^{-\mathrm{II}}$ and $\mathrm{pH}$ data suggest that the Black Sea's saturation point is near $150 \mathrm{~m}$ depth in the water column, whereas Cariaco's is located a few mm below the sediment-water interface (Helz and Vorlicek, 2019). Therefore, Cariaco's bottom waters are pre-asymptote, whereas the Black Sea's are syn-asymptote. Cariaco's sediments accumulate more $\mathrm{Mo}_{\mathrm{s}}$ by diffusion because of the very sharp, pre- to synasymptote $\mathrm{Mo}_{\mathrm{aq}}$ gradient across the sediment-water interface.

To summarise, the narrow range of $\mathrm{Mo}_{\mathrm{aq}, \infty}$ values that form in sulfidic water columns and pore waters characterised by enormous differences in POC concentrations preclude adsorption to organic matter as an important Mo fixation process in nature. In contrast, $\mathrm{FeMoS}_{4}$ precipitation, which depends on the thermodynamic activities of $\mathrm{H}^{+}, \mathrm{MoS}_{4}{ }^{2-}$, and $\mathrm{FeS}$ rather than their concentrations, readily explains why $\mathrm{Mo}_{\mathrm{aq}}$ asymptotes are independent of final sulfide and POC concentrations.

Editor: Liane G. Benning

\section{Additional Information}

Supplementary Information accompanies this letter at https:// www.geochemicalperspectivesletters.org/article2129.

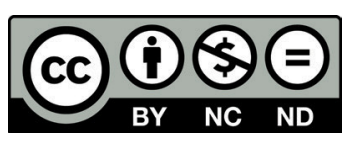

(C) 2021 The Authors. This work is distributed under the Creative Commons Attribution NonCommercial No-Derivatives 4.0 License, which permits unrestricted distribution provided the original author and source are credited. The material may not be adapted (remixed, transformed or built upon) or used for commercial purposes without written permission from the author. Additional information is available at https://www. geochemicalperspectivesletters.org/copyright-and-permissions.

Cite this letter as: Helz, G.R. (2021) Dissolved molybdenum asymptotes in sulfidic waters. Geochem. Persp. Let. 19, 23-26.

\section{References}

Algeo, T.J., Lyons, T.W. (2006) Mo-total organic carbon covariation in modern marine environments: Implication for analysis of paleoredox and paleohydrographic conditions. Paleooceanography and Paleoclimatology 21, PA1016.

Arthur, M.A., Dean, W.E., NefF, E.D., Hay, B.J., KING, J., Jones, G. (1994) Varve calibrated records of carbonate and organic carbon accumulation over the last 2000 years in the Black Sea. Global Biogeochemical Cycles 8, 195-217.

Dahl, T.W., Anbar, A.D., Gordon, G.W., Rosing, M.T., Frei, R., Canfield, D.E. (2010) The behavior of molybdenum and its isotopes across the chemocline and in the sediments of sulfidic Lake Cadagno, Switzerland. Geochimica et Cosmochimica Acta 74, 144-163.

EMERSON, S.R., Huested, S.S. (1991) Ocean anoxia and the concentrations of molybdenum and vanadium in seawater. Marine Chemistry 34, 177-196.

Glass, J.B., Wolfe-Simon, F., Elser, J.J., AnBar, A.D. (2010) Molybdenum-nitrogen co-limitation in freshwater and coastal heterocystous cyanobacteria. Limnology and Oceanography 55, 667-676.

Gu, Y., Gammons, C.H., Bloom, M.S. (1994) A one-term extrapolation method for estimating equilibrium constants of aqueous reactions at elevated temperatures. Geochimica et Cosmochimica Acta 58, 3545-3560.

Havig, J.R., McCormick, M.L, Hamiton, T.L, Kump, L.R. (2015) The behavior of biologically important trace elements across the oxic/euxinic transition of meromictic Fayettville Green Lake, New York, USA. Geochimica et Cosmochimica Acta 165, 389-406.

Helz, G.R., VorliceK, T.P. (2019) Precipitation of molybdenum from euxinic waters and the role of organic matter. Chemical Geology 509, 178-193.

Ho, P., Lee, J.-M., Heller, M.I., Lam, P.J., Shiller, A.M. (2018) The distributions of dissolved and particulate Mo and V along the U.S. GEOTRACES East Pacific zonal transect (GP16): The roles of oxides and biogenic particles in their distribution in the oxygen deficient zone and the hydrothermal plume. Marine Chemistry 201, 242-255.

Kaiser, D., Konovalov, S., Schulz-Bull, D.E., WanieK, J.J. (2017) Organic matter along longitudinal and vertical gradients in the Black Sea. Deep Sea Research Part I 129, 22-31.

Matamoros-Veloza, A., Cespedes, O., Johnson, B.R.G., Stawski, T.M., Terranova, U., DE LeeUw, N.H., BenNing, L.G. (2018) A highly reactive precursor in the iron sulfide system. Nature Communications 9, 3125

Morford, J.L., Martin, W.R., Kalnejais, L.H., François, R., Bopthner, M., Karle, I.M. (2007) Insights on geochemical cycling of $U$, Re and Mo from seasonal sampling in Boston Harbor, Massachusetts, USA. Geochimica et Cosmochimica Acta 71, 895-915.

Morford, J.L., Martin, W.R., Françis, R., CARNEY, C.M. (2009) A model for uranium, rhenium and molybdenum diagenesis in marine sediments based on results from coastal locations. Geochimica et Cosmochimica Acta 73, 2938-2960.

PIPER, D.Z., CALVERT, S.E. (2009 A marine biogeochemical perspective on black shale deposition. Earth-Science Reviews 95, 63-96.

Rolison, J.M., StirLing, C.H., MidDaG, R., RiIKENBERG, M.J.A. (2017) Uranium stable isotope fractionation in the Black Sea: Modern calibration of the ${ }^{238} \mathrm{U} /{ }^{235} \mathrm{U}$ paleo-redox proxy. Geochimica et Cosmochimica Acta 203, 69-88.

Sulu-Gambari, R., Roepert, A., Jilbert, T., Hagens, M., Meysman, F.J.R., Slomp, C.P. (2017) Molybdenum dynamics in sediments of a seasonally-hypoxic coastal marine basin. Chemical Geology 466, 627-640.

Vorlicek, T.P., Helz, G.R., Chappaz, A., Vue, P., Vezina, A., Hunter, W. (2018) Molybdenum burial mechanism in sulfidic sediments: iron-sulfide pathway. ACS Earth and Space Chemistry 2, 565-576.

Wolthers, M., Charlet, L., van der Linde, P.R., Rickard, D., van der Weidden, C.H. (2005) Surface chemistry of disordered mackinawite (FeS). Geochimica et Cosmochimica Acta 69, 3469-3481. 